\title{
What is the Difference between the Two Lateral X-Rays Taken During Left S1 Transforaminal Epidural Steroid Injection?
}

\section{Sol S1 Transforaminal Epidural Steroid Enjeksiyonu Sırasında Çekilen Iki Lateral Grafi Arasındaki Fark Nedir?}

\author{
Savaş ŞENCAN, Alp Eren ÇELENLIOĞLU, Osman Hakan GÜNDÜZ \\ Department of Physical Medicine and Rehabilitation, Marmara University Faculty of Medicine, Istanbul, Turkey
}

To the Editor,

A 54-year-old female patient was admitted to a physical medicine and rehabilitation (PM\&R) outpatient clinic with complaints of low back and radicular left leg pain for 5 months. Physical examination showed painful and limited lumbar flexion. Straight leg raise test was negative on the right and positive at 60 degrees on the left side. Bilateral patella and Achilles reflexes were normal. Left extensor hallucis longus muscle strength was $4 / 5$, and gastrocnemius muscle strength was found to be normal. Hypoesthesia was noted in the left S1 dermatome.

Magnetic resonance imaging (MRI) revealed a protrusion of the L5/S1 lumbar disc to the left compressing left S1 nerve root. With this physical examination and lumbar MRI findings, a left S1 transforaminal epidural steroid injection was planned. As she was on acetylsalicylic acid, it was stopped 1 week before the injection.

For the injection procedure, the patient was placed prone on the procedure table. After the sterilization of the patient's skin with providence iodine, a sterile drape was placed. The target left S1 foramen was found with fluoroscopy. By using the intermittent fluoroscopy, a 22-gauge, 3.5-inch spinal needle was introduced to the epidural area. A lateral picture was taken to confirm the needle position (Figure 1a); another image was taken after injecting 1-2 cc iohexol (Figure 1b).
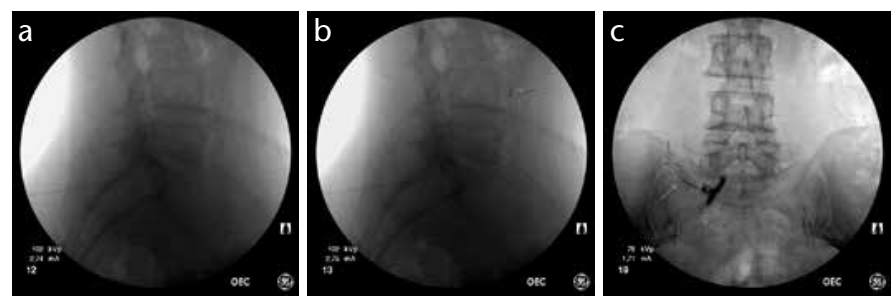

Figure 1. a-c. Lateral images taken during the left S1 transforaminal epidural injection $(a, b)$. Vascular distribution can be seen in the right image (b) and contrast is located in the abdominal aorta right after contrast injection (arrow). In the anteroposterior image (c) vascular uptake is seen (arrows)

Question: What is the difference between the two lateral images taken successively?

Answer: Vascular uptake.

In the lateral fluoroscopy X-ray image on the right, the contrast is seen in the abdominal aorta (arrow) at the L4 level right after its injection (Figure 1b). Vascular uptake is seen along with the left S1 epidural contrast distribution (arrows) (Figure 1c).

Imaging is an essential component in modern interventional spinal procedures. The reason for using imaging is first to confirm reaching the desired target area and second to confirm that the needle tip is not in the vascular scape. For the first aim, 
fluoroscopy, computed tomography (CT), and ultrasound can be employed. However, for the latter, contrast is used, and this is only possible with fluoroscopy and CT, as ultrasound can not exclude vascular distribution. Studies show that even experienced physicians fail in the injections without fluoroscopy in about $25 \%-30 \%$ of the cases (1). In addition, the risk of intravascular injection of medications, especially local anesthetics, is very important. During an interventional procedure, if vascular uptake is observed, the needle should be repositioned, and contrast is injected again until the correct needle position at the target is maintained and there is no vascular distribution. Potential problems associated with intravascular injection include anesthetic toxicity, which can cause seizures, cardiac arrest, burning pain, and anaphylactic reactions from corticosteroids (2). In this patient, we got rid of the vascular area with minimal needle movement, and once the target was reached with no vascular uptake, we injected the medications.

It is also reported that intravascular injection is seen in $6.4 \%-$ $10.9 \%$ in cervical and $10.8 \%-11.2 \%$ in lumbar transforaminal procedures (3).

The patient was assessed an hour after the injection. Visual analog scale (VAS) scores for pain decreased from $8 / 10$ to $3 / 10$.

Transforaminal epidural injection is an effective method for treating spinal pain but can cause devastating complications that result from accidental vascular uptake of the injectate or direct vascular injury (4). For these reasons, transforaminal epidural injection will never be risk-free, but the safest method of injection is with the fluoroscopically guided, contrast-confirmed method, which should be considered the current standard of care.

Peer-review: Externally peer-reviewed.

Author Contributions: Concept - O.H.G.; Design - O.H.G., S.Ş.; Supervision - O.H.G., S.Ş.; Funding - O.H.G., S.Ş.; Materi- als - A.E.Ç.; Data Collection and/or Processing - O.H.G., A.E.Ç.; Analysis and/or Interpretation - O.H.G., S.Ş., A.E.Ç.; Literature Review - O.H.G., S.Ş., A.E.Ç.; Writer - O.H.G., S.Ş.; Critical Review - O.H.G., S.Ş., A.E.Ç.; Other - O.H.G., S.Ş., A.E.Ç.

Conflict of Interest: No conflict of interest was declared by the authors.

Financial Disclosure: The authors declared that this study has received no financial support.

Hakem değerlendirmesi: Dış bağımsız.

Yazar Katkıları: Fikir - O.H.G.; Tasarım - O.H.G., S.Ş.; Denetleme - O.H.G., S.Ş.; Kaynaklar - O.H.G., S.Ş.; Malzemeler - A.E.Ç.; Veri toplanması ve/veya işlemesi - O.H.G., A.E.Ç.; Analiz ve/veya yorum - O.H.G., S.Ş., A.E.Ç.; Literatür taraması - O.H.G., S.Ş., A.E.Ç.; Yazıyı yazan - O.H.G., S.Ş.; Eleştirel İnceleme - O.H.G., S.Ş., A.E.Ç.; Diğer - O.H.G., S.Ş., A.E.Ç.

Çıkar Çatışması: Yazarlar çıkar çatışması bildirmemişlerdir.

Finansal Destek: Yazarlar bu çalışma için finansal destek almadıklarını beyan etmişlerdir.

\section{References}

1. Manchikanti L, Cash KA, Pampati V, McManus CD, Damron KS. Evaluation of fluoroscopically guided caudal epidural injections. Pain Physician 2004;7:81-92.

2. Sullivan W], Willick SE, Chira-Adisai W, Zuhosky J, Tyburski M, Dreyfuss $P$, et al. Incidence of intravascular uptake in lumbar spinal injection procedures. Spine 2000;25:481-6. [CrossRef]

3. DePalma MJ, Slipman CW. Evidence-informed management of chronic low back pain with epidural steroid injections. Spine J 2008;8:45-55. [CrossRef]

4. Nahm FS, Lee C], Lee SH, Kim TH, Sim WS, Cho HS, et al. Risk of intravascular injection in transforaminal epidural injections. Anaesthesia 2010;65:917-21. [CrossRef] 